\title{
PERI-TUMORAL INFLAMMATORY CELL INFILTRATION IN OSCC: A RELIABLE MARKER OF LOCAL RECURRENCE AND PROGNOSIS? AN INVESTIGATION USING ARTIFICIAL NEURAL NETWORKS
}

\author{
G. CAMPISI ${ }^{1}$, F. CALVINO ${ }^{1}$, F. CARINCI ${ }^{2}$, D. MATRAGNA ${ }^{3}$, \\ M. CARELLA ${ }^{4}$, M. MAZZOTTA ${ }^{5}$, C. RUBINI ${ }^{6}$, V. PANZARELLA ${ }^{1}$, \\ A. SANTARELLI ${ }^{4}$, S. FEDELE ${ }^{7}$, L. LO MUZIO ${ }^{4,5}$

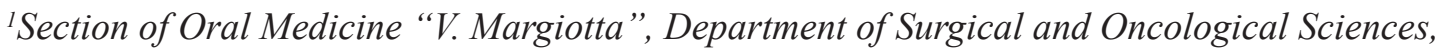 \\ University of Palermo, Palermo, Italy \\ ${ }^{2}$ Department of D.M.C.C.C., Section of Maxillofacial Surgery, University of Ferrara, Ferrara, Italy \\ ${ }^{3}$ Deptartment of Biopathology and Medical and Forensic Biotechnologies, University of Palermo, Italy \\ ${ }^{4}$ Department of Surgical Sciences, University of Foggia, Foggia, Italy \\ ${ }^{5}$ IRCCS CROB, Centro di Riferimento Oncologico di Basilicata, Rionero in Vulture, Potenza, Italy \\ ${ }^{6}$ Department of Neuroscience, Politecnica University of Marche, Ancona, Italy \\ ${ }^{7}$ UCL Eastman Dental Institute, London, United Kingdom
}

The presence of inflammatory reaction in peri-tumoural connective tissue is generally considered as a defense mechanism against cancer, but inflammation tissue in malignant transformation and early steps of oncogenesis has been recently proven to play a supporting and aggravating role in some carcinomas. To evaluate in OSCCs the independent association of peri-tumoral inflammatory infiltrate (PTI) with local recurrence (LR) or survival outcome, and to verify whether PTI can be considered a marker of prognosis. Data from 211 cases of OSCC, only surgically treated between 1990 and 2000, were collected and retrospectively analyzed for PTI and the event LR (5 yrs follow-up at least) by means of univariate-multivariate and neural networks analyses. Patients (mean age 65.3 $\pm 12.4 \mathrm{yrs}, \mathrm{M} / \mathrm{F}=2.98)$ showed presence of PTI in $68.2 \%(144 / 211):(+)$ in $27.0 \%,(++)$ in $25.6 \%,(++) 15.6 \%$; PTI was found reduced in $24.7 \%$ of cases and absent in $7.1 \%$. In overall PTI+ve group $(n=144), 66$ were TNM Stage I, 33 Stage II, 45 Stage III, none Stage IV. LR (mean $6 \pm 4$ months) was present in 87/211 (41.2\%) patients, of which 43/144 (29.8\%) in OSCCs with PTI [23 in PTI+ve $(+), 13$ in $(++)$ and 7 in $(+++)]$ vs. 44/67 (65.7\%) in PTI $-/+$ or -ve ones. By univariate analysis, PTI+ve cases showed a significant lower risk to have $L R(p<0.0001 ; 0 R=0.2297$; $\mathrm{CI}=0.1277: 0.4134)$ vs $\mathrm{PTI}-/+$ or - ve ones, especially among cases with higher $\mathrm{PTI}$ value $(+++)(\mathrm{OR}=0.1718$; $\mathrm{CI}=$ 0.0749:0.3939). Multivariate analyses (Logit model and neural networks) confirmed the same datum: presence of PTI was an independent predictive variable accounting for a better tumoural outcome without LR (Logit and neural networks values: $O R^{\prime} 0.226$; $C I=0.113: 0.454$; $R O C$ Area $=0.66$, respectively). In terms of prognostic significance, elevated PTI was found to have an independent association with the poorest overall survival rate (P $=0.056$ ). Our findings strongly suggest the importance to investigate routinely PTI in OSCCs, as useful marker of tumoral behavior and prognosis, and warrant further studies on its specific cellular nature.

The presence of inflammatory cells in the peri-tumoral microenvironment is a common feature of many cancers, yet there remains significant controversy regarding its role with respect to tumor development, progression and spreading.
Peri-tumoral inflammation has been traditionally considered to represent a defense mechanism against cancer progression and invasion (1). Indeed the absence of tumor-associated lympocytes has been reported to represent a negative prognostic factor in a number of

Keywords: oral carcinoma, recurrence, survival rate, marker

Corresponding author: Prof. Francesco Carinci, M.D

Department of D.M.C.C.C. Section of Maxillofacial Surgery

University of Ferrara Corso Giovecca 203

44100 Ferrara ITALY

0394-6320 (2011)

E-mail: crc@unife.it

Web: www.carinci.org

Phone/Fax: +39.0532 .455582$ 
human malignancy including cutaneous melanoma, colorectal, breast, ovarian, and endometrial cancer (2).

Nonetheless, there is increasing evidence that peritumoral stromal inflammation is more likely to contribute to cancer development, growth and progression than mounting an effective host anti-cancer response (3). Several studies have highlighted that cancer cells can promote local migration of myelomonocytic cells which, in turn, can express inflammatory mediators supporting pro-tumoral functions such as cell proliferation and survival, angiogenesis, stroma remodeling and metastasis formation (4). Overall there remain significant controversy and unclear aspects upon the mechanisms that determine and orchestrate the differences between these two identities of peri-tumoral inflammation, namely the chronic smoldering inflammation promoting cancer-cell growth and survival versus the cytotoxic inflammatory reaction triggering cancer cell destruction (5).

Little is known regarding the role of the peri-tumoral inflammatory infiltrate (PTI) of oral squamous cell carcinoma (6), an aggressive epithelial malignancy that is characterized by a strong tendency to loco-regional spreading, lymph node metastases, local recurrences, and an overall poor prognosis. There remains little evidence suggesting whether or not the presence and the characteristics of PTI of oral squamous cell carcinoma (i) correlate with prognosis, (ii) could be used to predict clinical behavior and plan individualized treatment strategies (7). The aim of the present study was to investigate the role of PTI as independent prognostic factor for LR or survival outcome in a series of 211 patients with oral squamous cell carcinoma.

Data were studied using two statistical models: traditional univariate/multivariate analysis and artificial neural network (ANN). The advantages of ANN in detecting causal relationships among multiple factors that operates synergically and in correcting for multiple potential confounders has been reported before.

\section{MATERIALS AND METHODS}

\section{Research aim and hypothesis}

The aim of the present study was to investigate if the presence and grade of PTI could affect the incidence rate of LR and 5-year survival in patients with OSCC. The null hypothesis was that the LR incidence and 5-year survival rate would not vary regardless of the presence and grade of PTI

\section{Study population}

This was a retrospective study of histopathological specimens and clinical data relevant to a cohort of 211 patients who were diagnosed with oral squamosu cell carcinoma (OSCC) between 1990 and 2000 in the Sector of Maxillofacial Surgery (Politecnica delle Marche Ancona, Italy).
All patients received surgical resection of the primary tumor with curative intention, followed by cervical/submandibular lymphadenectomy and/or radiotherapy where indicated. Tumors were staged according to International Union Against Cancer (UICC) TNM system (8).

Data regarding primary tumor stage and initial treatment, as well as subsequent local recurrences, second primary tumors, lymph node or distant organ metastases, and related therapy for a period of at least 5 years were collected from clinical notes of all patients.

\section{Histopathological analysis and PTI definition}

Evaluation of histopathological specimens and slides was performed independently by two authors of the present paper (CR, TP) and include (i) OSCC diagnosis and grading, (ii) OSCC grading at deep invasive front and (iii) assessment and grading of PTI. Grading of PTI was performed on the basis of the number of inflammatory cells: (-) if PTI was absent, ($/+)$ if PTI was very mild, $(+)$ if PTI was mild, $(++)$ if PTI was moderate, and $(+++)$ if PTI was intense. The analysis of PTI was determinated by $\mathrm{T}$ lymphocytes and $\mathrm{B}$ lymphocytes infiltration as described in Viera et al 2008 (9).

\section{Prognostic outcomes and other variables}

The following prognostic outcomes were considered: local recurrence, 5-year survival. Local recurrence (LR) was defined as tumor recurrence in the primary region after initial treatment, documented by surgical biopsy and histological evaluation. Other variables considered for data analysis included: tumor staging and grading, patient age and gender.

\section{Univariate and multivariate statistical analysis}

The data were analyzed by means of StatView for Windows (SAS Inc v. 5.0.1, Cary, NC, USA) and Statistica 6.0 (Statsoft Inc, Tulsa, OK, USA). The crude Odds Ratio (OR) and the 95\% corresponding test-based Confidence Interval (CI) were calculated to measure the association level. The Chi-square test was used to assess statistical differences among categorical variables; $p$-values $\leq 0.05$ for all evaluations were considered statistically significant. Regarding the criteria of acceptability, variables such as age and tumor size were categorized into nominal ones by utilizing the median values. Reference groups were chosen as follows: regarding an ordinal variable (e.g. age), the first category was chosen as the reference group; for other features, the category with the largest number was chosen as that reference group.

The relationship between LR occurrence and PTI, and the connection between survival outcome and other variables, was analyzed within univariate and multivariate frameworks. A logistic regression model was constructed, given the dichotomous nature of LR and outcome variables. A stepwise selection procedure was applied to obtain the most parsimonious model. The Maximum Likelihood Ratio (MLR) and Adjusted Odds Ratio (OR') were obtained using the iterative weighted least squares procedure. The 5-year survival rate was evaluated by the well-known Kaplan-Meier and Cox regression methods. The log-rank test was utilized for evaluating the differences in observed survival between groups. Regarding survival rate analysis, we categorized the deceased (due to OSCC) patients as 
uncensored; the remaining patients were classified as censored.

Artificial neural network (ANN) analysis

Following a blinded procedure, three ANN models (see Fig. 1 for PTI vs. LR system) were applied to the same data; fully connected multilayer feedforward networks were also used. The learning rule was the well-known Back-error Propagation (BP) that adjusts the internal parameters of the networks over repeated training cycles to reduce the overall error (10). The networks were validated with a new set of data, different from the training ones, and the performance measured by: i) Mean Squared Error (MSE), Accuracy, Sensitivity and Specificity values; and ii) the Receiver Operating Characteristic (ROC) area, both effective at establishing the degree of meaningful prediction (11). Moreover, these indexes permit a comparison of performance between logistic regression and ANN systems. Regarding the latter, all variables were selected as input ones, except for LR presence, survival outcome and survival rate, which are all considered as output variables. No data variation is required because the ANNs can handle both numerical and nominal data.

\section{RESULTS}

The characteristics of the study population are reported in Table I, while details regarding features of sample grouped by LR are described in Table II.

ORs from PTI $-/+$ were found to be overlapping in the univariate preliminary analysis as compared to those of PTI $-\mathrm{ve}(\mathrm{p}>0.2)$. Hence, we additionally labeled all cases PTI $-/+$ and $-\mathrm{ve}$ as negative. The main finding with univariate analysis was: overall PTI positive cases displayed a significantly lower risk $(\mathrm{p}<0.0001$; $\mathrm{OR}=0.2297$ and $95 \% \mathrm{CI}=0.1277: 0.4134)$ of $\mathrm{LR}$ vs. negative PTI, especially cases with a higher PTI value $(+++)$ (Table II). Even if other independent variables (site, tumor size, predominant grading, IFG and peri-neural infiltration) proved to be statistically significant risks for developing LR, PTI was identified as the most significant factor in the stepwise selection procedure (OR' 0.226 ; $\mathrm{CI}=$ 0.113:0.454). Specifically, Logistic Classification revealed an overall percentage of the correct estimate equal to $72.51 \%$. Performance indexes (i. e. Methods) (LR +ve as positive and LR -ve as negative) were: accuracy $=72.51 \%$, sensitivity $=60.92 \%$, specificity $=80.65 \%$.

Similarly, the ANN methodology proved that PTI was the most meaningful variable influencing LR in the present dataset, with an MSE equal to 0.43. Performance indexes possessed the following values: accuracy = $63.50 \%$; sensitivity $=54.03 \%$, and specificity $=77.01 \%$. The ROC area was equal to 0.66 .

As regards survival outcome, all results relating to univariate analysis are reported in Table III. The main result was that the most meaningful variables were all those which had been considered except age, gender and site, whereas, in multivariate analysis, it was found that
Table I. Characteristics of study population

\begin{tabular}{|c|c|c|c|c|}
\hline Variables & no. & $\begin{array}{l}\text { percentage } \\
(\%)\end{array}$ & mean $($ S.D*) & range \\
\hline cases & 211 & & & \\
\hline age (years) & & & $65.3(12.4)$ & $28-95$ \\
\hline $\begin{array}{l}\text { sex } \\
\text { Male } \\
\text { Female }\end{array}$ & $\begin{array}{l}153 \\
58\end{array}$ & $\begin{array}{l}72.5 \\
27.5\end{array}$ & & \\
\hline $\begin{array}{l}\text { histological grade } \\
\text { G1 } \\
\text { G2 } \\
\text { G3 }\end{array}$ & $\begin{array}{l}86 \\
29 \\
96\end{array}$ & $\begin{array}{l}40.8 \\
13.7 \\
45.5\end{array}$ & & \\
\hline $\begin{array}{l}\text { invasive front grading } \\
\text { G1 } \\
\text { G2 } \\
\text { G3 }\end{array}$ & $\begin{array}{l}77 \\
51 \\
83\end{array}$ & $\begin{array}{l}36.5 \\
24.2 \\
39.3 \\
\end{array}$ & & \\
\hline $\begin{array}{l}\text { tumor Size }(\mathbf{c m}) \\
\text { T1 } \\
\text { T2 } \\
\text { T3 }\end{array}$ & $\begin{array}{l}104 \\
74 \\
33\end{array}$ & $\begin{array}{l}49.3 \\
35.1 \\
15.6\end{array}$ & $2.23(1.24)$ & $0.6-6.0$ \\
\hline $\begin{array}{l}\text { regional lymph nodes } \\
\text { N0 } \\
\text { N1 }\end{array}$ & $\begin{array}{l}167 \\
44\end{array}$ & $\begin{array}{l}79.1 \\
20.9\end{array}$ & & \\
\hline $\begin{array}{l}\text { staging } \\
\text { I } \\
\text { II } \\
\text { III } \\
\text { IV }\end{array}$ & $\begin{array}{l}96 \\
44 \\
71 \\
0\end{array}$ & $\begin{array}{l}45.5 \\
20.9 \\
33.6 \\
0\end{array}$ & & \\
\hline $\begin{array}{l}\text { oral site } \\
\text { tongue } \\
\text { gingiva } \\
\text { mucosa } \\
\text { sublingual }\end{array}$ & $\begin{array}{l}104 \\
27 \\
61 \\
19\end{array}$ & $\begin{array}{l}49.3 \\
12.8 \\
28.9 \\
9.0\end{array}$ & & \\
\hline $\begin{array}{l}\text { perineural infiltration } \\
\text { No } \\
\text { Yes }\end{array}$ & $\begin{array}{l}112 \\
99\end{array}$ & $\begin{array}{l}53.1 \\
46.9\end{array}$ & & \\
\hline $\begin{array}{l}\text { PTI score } \\
(-) \\
(-/+) \\
(+) \\
(++) \\
(+++)\end{array}$ & $\begin{array}{l}15 \\
52 \\
57 \\
54 \\
33\end{array}$ & $\begin{array}{l}7.1 \\
24.7 \\
27.0 \\
25.6 \\
15.6\end{array}$ & & \\
\hline $\begin{array}{l}\text { recurrence } \\
\text { No } \\
\text { Yes }\end{array}$ & $\begin{array}{l}124 \\
87\end{array}$ & $\begin{array}{l}58.8 \\
41.2\end{array}$ & & \\
\hline
\end{tabular}

* S.D = Standard Deviation

only PTI and LR were identified as the best markers: PTI demonstrated a progressively protective role $\left(\mathrm{OR}^{\prime}=0.430\right.$, $\mathrm{CI}=0.205: 0.902)$, whilst $\mathrm{LR}$ was confirmed as a risk factor $\left(\mathrm{OR}^{\prime}=4.867, \quad \mathrm{CI}=2.437: 9.72\right)$. Considering the deceased patients as having positive values and the living 
Table II. Characteristics and risk factors grouped by Local Recurrences (LR)

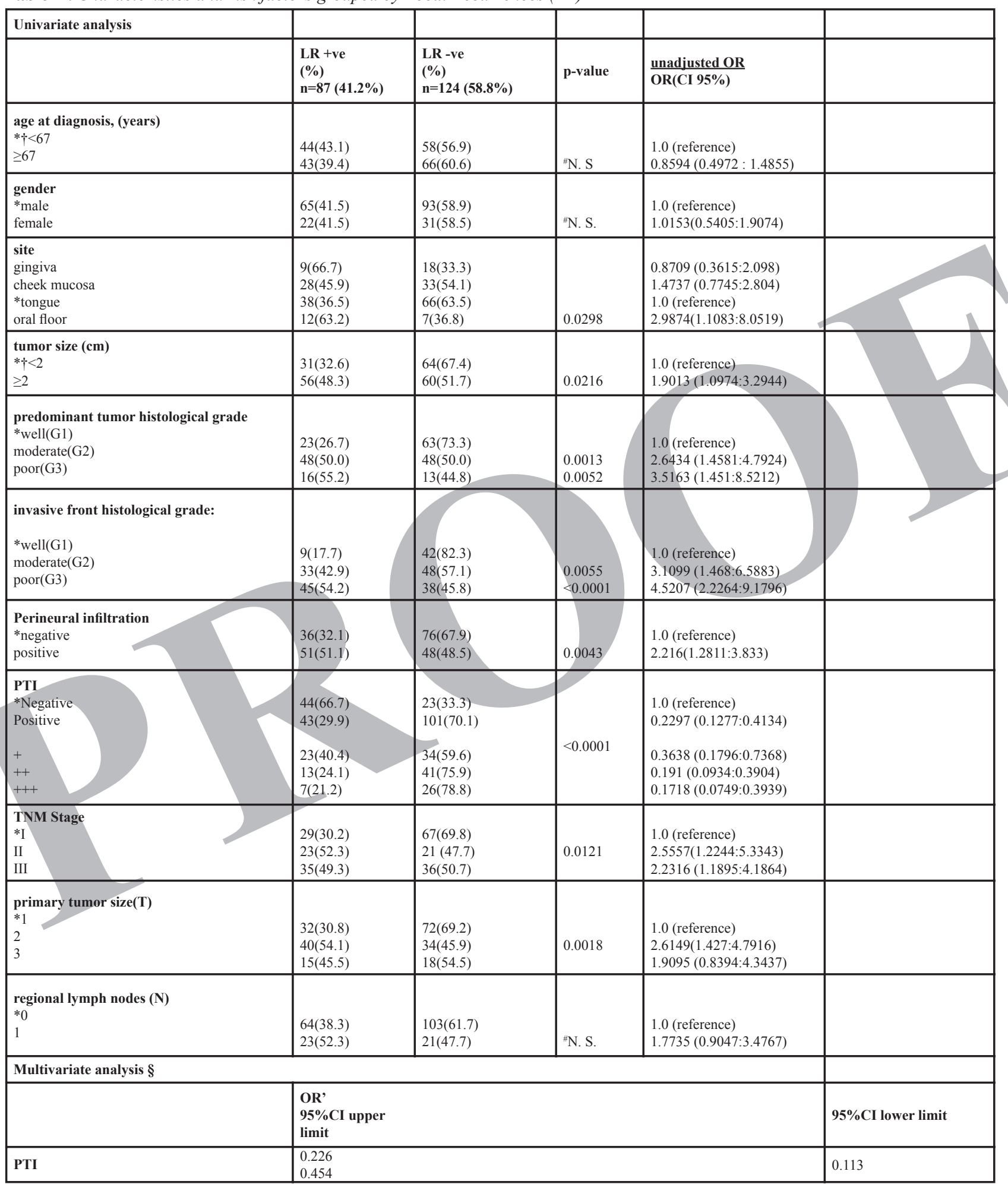

*Reference group for OR calculation. For details, see Materials and Methods

† Median value in comprehensive sample

"Not significant 
Table III. Characteristics and risk factors for survival outcome

\begin{tabular}{|c|c|c|c|c|}
\hline \multicolumn{5}{|l|}{ Univariate analysis } \\
\hline & $\begin{array}{l}\text { alive } \\
(\%) \\
\text { n=107 } \\
(\mathbf{5 0 . 7 \% )}\end{array}$ & $\begin{array}{l}\text { deceased } \\
(\%) \\
n=104 \\
(49.3 \%)\end{array}$ & p-value & $\frac{\text { unadjusted OR }}{\text { OR(CI 95\%) }}$ \\
\hline $\begin{array}{l}\text { age at diagnosis, } y \\
* \uparrow<67 \\
\geq 67\end{array}$ & $\begin{array}{l}56(54.9) \\
51(46.8)\end{array}$ & $\begin{array}{l}46(45.1) \\
58(53.2)\end{array}$ & ${ }^{*} \mathrm{~N} . \mathrm{S}$ & $\begin{array}{l}1.0 \text { (reference) } \\
1.3813(0.8059: 2.3675)\end{array}$ \\
\hline $\begin{array}{l}\text { gender } \\
\text { *male } \\
\text { female }\end{array}$ & $\begin{array}{l}82(51.9) \\
25(47.2)\end{array}$ & $\begin{array}{l}76(48.1) \\
28(52.8)\end{array}$ & "N. S & $\begin{array}{l}1.0 \text { (reference) } \\
1.2072(0.6489: 2.246)\end{array}$ \\
\hline $\begin{array}{l}\text { site } \\
\text { gingiva } \\
\text { cheek mucosa } \\
\text { *tongue } \\
\text { oral floor }\end{array}$ & $\begin{array}{l}13(48.1) \\
30(49.2) \\
58(55.8) \\
6(31.6) \\
\end{array}$ & $\begin{array}{l}14(51.9) \\
31(50.8) \\
46(44.2) \\
13(68.4)\end{array}$ & ${ }^{*} \mathrm{~N} . \mathrm{S}$ & $\begin{array}{l}1.3562(0.5817: 3.1617) \\
1.301(0.6917: 2.4469) \\
1.0(\text { reference }) \\
2.6152(0.9866: 6.9321)\end{array}$ \\
\hline $\begin{array}{l}\text { tumor size (cm) } \\
*_{\dagger}<2 \\
\geq 2\end{array}$ & $\begin{array}{l}58(61.1) \\
49(42.2)\end{array}$ & $\begin{array}{l}37(38.9) \\
67(57.8)\end{array}$ & 0.0065 & $\begin{array}{l}1.0 \text { (reference) } \\
2.115(1.231: 3.6336)\end{array}$ \\
\hline $\begin{array}{l}\text { predominant tumor } \\
\text { histological grade } \\
\text { well }(\mathrm{G} 1) \\
\text { *moderate }(\mathrm{G} 2) \\
\text { poor(G3) }\end{array}$ & $\begin{array}{l}52(60.5) \\
44(45.8) \\
11(37.9) \\
\end{array}$ & $\begin{array}{c}34(39.5) \\
52(54.2) \\
18(62.1) \\
\end{array}$ & 0.0484 & $\begin{array}{l}0.5578(0.3119: 0.9975) \\
1.0 \text { (reference) } \\
1.3746(0.5974: 3.1628) \\
\end{array}$ \\
\hline $\begin{array}{l}\text { invasive front hist } \\
\text { grade } \\
\text { well(G1) } \\
\text { moderate }(\mathrm{G} 2) \\
\text { * poor }(\mathrm{G} 3)\end{array}$ & $\begin{array}{l}35(68.6) \\
39(50.7) \\
33(39.8)\end{array}$ & $\begin{array}{l}16(31.4) \\
38(49.3) \\
50(60.2)\end{array}$ & 0.0012 & $\begin{array}{l}0.3178(0.1586: 0.6367) \\
0.6458(0.3469: 1.2022) \\
1.0 \text { (reference) }\end{array}$ \\
\hline $\begin{array}{l}\text { Perineural infiltrati } \\
\text { *No } \\
\text { Yes }\end{array}$ & $\begin{array}{l}67(59.8) \\
40(40.4)\end{array}$ & $\begin{array}{l}45(40.2) \\
59(59.6)\end{array}$ & 0.0049 & $\begin{array}{l}1.0 \text { (reference) } \\
2.1666(1.2632: 3.7162)\end{array}$ \\
\hline $\begin{array}{l}\text { PTI }\left(2^{\circ} \text { analysis }\right) \\
\text { *Negative } \\
\text { Positive }\end{array}$ & $\begin{array}{l}20(29.9) \\
87(60.4)\end{array}$ & $\begin{array}{l}47(70.1) \\
57(39.6)\end{array}$ & $<0.0001$ & $\begin{array}{l}1.0 \text { (reference) } \\
0.2961(0.166: 0.528)\end{array}$ \\
\hline $\begin{array}{l}\text { TNM Stage } \\
\text { *I } \\
\text { II } \\
\text { III }\end{array}$ & $\begin{array}{l}59(61.5) \\
20(45.5) \\
28(39.4)\end{array}$ & $\begin{array}{l}37(38.5) \\
24(54.5) \\
43(60.5)\end{array}$ & 0.0049 & $\begin{array}{l}1.0 \text { (reference) } \\
1.9084(0.9317: 3.9091) \\
2.404(1.3032: 4.4345)\end{array}$ \\
\hline $\begin{array}{l}\text { primary tumor size } \\
* 1 \\
2 \\
3\end{array}$ & $\begin{array}{c}63(60.6) \\
30(40.5) \\
14(42.4)\end{array}$ & $\begin{array}{l}41(39.4) \\
44(59.5) \\
19(57.6)\end{array}$ & 0.0083 & $\begin{array}{l}1.0(\text { reference }) \\
2.2224(1.2257: 4.0295) \\
2.0794(0.9471: 4.5653)\end{array}$ \\
\hline $\begin{array}{l}\text { regional lymph nod } \\
*_{0} \\
1\end{array}$ & $\begin{array}{c}91(54.5) \\
16(36.4) \\
\end{array}$ & $\begin{array}{l}76(45.5) \\
28(63.6) \\
\end{array}$ & 0.034 & $\begin{array}{l}1.0 \text { (reference) } \\
2.0581(1.0608: 3.9931) \\
\end{array}$ \\
\hline $\begin{array}{l}\text { recurrence } \\
\text { *No } \\
\text { Yes }\end{array}$ & $\begin{array}{l}85(68.5) \\
22(25.3)\end{array}$ & $\begin{array}{l}39(31.5) \\
67(74.7)\end{array}$ & $<0.0001$ & $\begin{array}{l}1.0(\text { reference }) \\
5.7258(3.3256: 9.8581)\end{array}$ \\
\hline \multicolumn{5}{|c|}{ Multivariate analysis $\S$} \\
\hline & OR' & \begin{tabular}{|l} 
95\%CI lower \\
limit \\
\end{tabular} & \begin{tabular}{|l}
$95 \%$ CI upper \\
limit \\
\end{tabular} & MLR test $\mathrm{p}$ value \\
\hline $\begin{array}{l}\text { PTI } \\
\text { recurrence }\end{array}$ & $\begin{array}{l}0.430 \\
4.867\end{array}$ & $\begin{array}{l}0.205 \\
2.437\end{array}$ & $\begin{array}{l}0.902 \\
9.72\end{array}$ & $\begin{array}{l}0.00249 \\
<0.0001\end{array}$ \\
\hline
\end{tabular}

*Reference group for OR calculation. For details see Materials and Methods

† Median value in comprehensive sample

"Not significant 


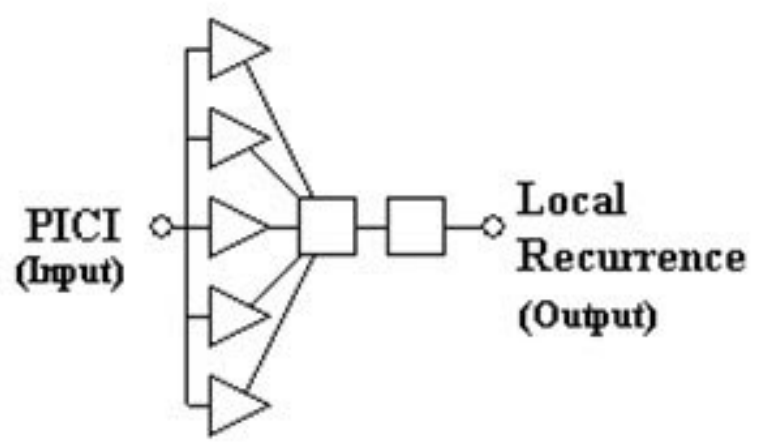

(Layers)

Fig. 1. ANN structure applied in the study

as negative, accuracy was $73.93 \%$, sensitivity $69.23 \%$ and specificity $78.50 \%$.

When applied to the same outcome problem, the ANN system performed well with an MSE equal to 0.3137; the area under the ROC curve was 0.8746 . The meaningful variables were PTI, LR, IFG and staging (accuracy = $78.56 \%$, sensitivity $=67.74 \%$, specificity $=90.59 \%$ ).

The analysis of the 5-year survival rate revealed that the highest mean lifetime was associated with PTI +ve cases and in LR-ve patients (p-value log-rank test < 0.0001)(Fig 2). Moreover, utilizing the Cox method, the LR variable proved to be the most meaningful (MLR $p$ $<0.001$, OR' $=0.206$ ). ANN performance was good (RMS 5.36) and the selected variables, in order of importance, were: LR, stage, PTI, peri-neural infiltration, IFG, predominant grading.

We also looked for secondary relationships among the survival outcome, survival rate and all of the variables considered, regardless of LR, by repeating the aforementioned analyses. With respect to survival outcome, the PTI variable proved to be the only significant variable in the logistic analysis (p-value 0.0001 by MLR, $95 \% \mathrm{CI}=0.077: 0.416$; accuracy $=75.42 \%$; sensitivity $=$ $62.50 \%$, specificity $=84.11 \%$ ), while the most meaningful variables of the survival rate were: PTI $\left(\mathrm{OR}^{\prime}=1.808\right)$, IFG $\left(\mathrm{OR}^{\prime}=0.415\right)$, peri-neural infiltration $\left(\mathrm{OR}^{\prime}=0.894\right)$, $\mathrm{T}\left(\mathrm{OR}^{\prime}=0.558\right), \mathrm{N}\left(\mathrm{OR}^{\prime}=0.660\right)$.

\section{DISCUSSION}

The overall incidence of OSCC, the most frequent malignant tumor of the oral cavity, has progressively increased in recent decades. Paradoxically, in spite of an improvement in therapeutic procedures, it shows a generally poor prognosis due to its local aggressiveness and metastases either in young than in old individuals (12).

As PTI has been considered a defense mechanism against cancer in several types of human neoplasia (13), the ability of PTI to influence the Odds Ratio of LR on OSCC was investigated in this study, using traditional statistics and ANN system analyses. The latter revealed that the presence of PTI acts as an independent predictive variable accounting for a better tumoral outcome without LR.

The importance of host response against tumor cells has been observed in several previous reports (14-16)

Having proven the protective effect of PTI in OSCC outcome, our study investigated: the influence of PTI in 1) LR rate and the 2) survival outcome in patients affected by OSCC. Regarding survival rate and 5-year outcome, the statistical tools demonstrated that the most meaningful variables were PTI and LR, as also confirmed by ANNs. As expected, patients with LR had a poorer survival

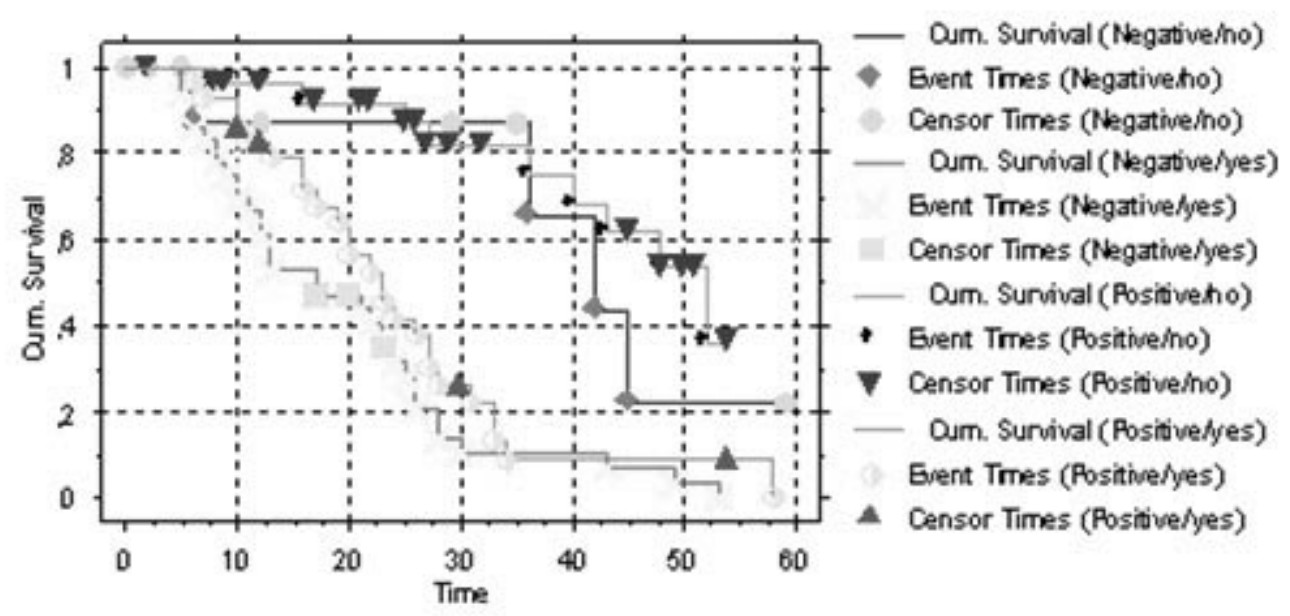

Fig. 2. Kaplan-Meier survival plot, according to PTI grouping (negative/positive) and LR stratification (yes/no) 
rate than subjects without LR and, consistent with our aforementioned findings, cases with PTI had a better survival rate than cases without PTI.

In this study, in which we investigated only inflammation infiltrate in peri-tumoral connective tissue, the flogistic response has demonstrated a protective effect against tumors: the inflammatory cells in peritumoral connective tissue may well represent a mature 'defence line' in opposition to the 'enemy'. Conversely, inflammatory cells infiltrating the tumor could be considered as the 'front-line troops' which, due to a lack of maturation or proximity (e.g. the paracrine mechanism), are 'taken prisoner' and recruited by neoplastic cytokines cells. Our understanding of the mechanisms of cytokines and chemokines is inchoate and greater efforts will be required to elucidate the relationship between neoplastic and inflammatory cells.

To the best of our knowledge, ours is the first report in which Artificial Neural Network system (ANNs) have been used in the largest sample size of OSCC patients to investigate which clinico-pathological variables could exert an influence on biological behavior and long-term outcomes in OSCC. ANNs are non-linear regression computational tools which have been used in classification and survival prediction in several biomedical systems. They are able to detect non-linearities among variables relating to interest, learning and adaptability, and they possess robustness and noise tolerance (17).

In conclusion, the null hypotheses considered as our primary endpoints were verified as PTI expression was found to be a reliable inverse marker of LR and a positive prognostic factor in terms of survival outcome and rate. This suggests the importance of investigating PTI-specific cellular nature and to routinely survey PTI in OSCC. Moreover, taking in account this aspect, the role of PTI can be further investigated in other age-related cancer as for example prostatic cancer. To conclude, in our study, ANNs has showed to perform better with respect to the traditional statistics for survival outcome analyses, warranting their ever-increasing use in this field of clinical oncology.

\section{REFERENCES}

1. Nespoli A, Gianotti L, Totis M, Bovo G, Nespoli L, Chiodini P, Brivio F. Correlation between postoperative infections and long-term survival after colorectal resection for cancer. Tumori 2004; 90:485-90.

2. Denkert C, Loibl S, Noske A, Roller M, Muller BM, Komor M, Budczies J, Darb-Esfahani S, Kronenwett R, Hanusch C, von Torne C, Weichert W, Engels K, Solbach C, Schrader I, Dietel M, von Minckwitz G. Tumor-associated lymphocytes as an independent predictor of response to neoadjuvant chemotherapy in breast cancer. J Clin Oncol 2010; 28:105-13.

3. Allavena P, Sica A, Solinas G, Porta C, Mantovani A. The inflammatory micro-environment in tumor progression: the role of tumor-associated macrophages. Crit Rev Oncol Hematol 2008; 66:1-9.

4. Sica A, Rubino L, Mancino A, Larghi P, Porta C, Rimoldi M, Solinas G, Locati M, Allavena P, Mantovani A. Targeting tumour-associated macrophages. Expert Opin Ther Targets 2007; 11:1219-29.

5. Mantovani A, Romero P, Palucka AK, Marincola FM. Tumour immunity: effector response to tumour and role of the microenvironment. Lancet 2008; 371:771-83.

6. Reichert TE, Scheuer C, Day R, Wagner W, Whiteside TL. The number of intratumoral dendritic cells and zeta-chain expression in $\mathrm{T}$ cells as prognostic and survival biomarkers in patients with oral carcinoma. Cancer 2001; 91:2136-47.

7. Uppaluri R, Dunn GP, Lewis JS, Jr. Focus on TILs: prognostic significance of tumor infiltrating lymphocytes in head and neck cancers. Cancer Immun 2008; 8:16.

8. UICC. TNM Classification of malignant tumours 2002;

9. Viera AJ. Odds ratios and risk ratios: what's the difference and why does it matter? South Med J 2008; 101:730-4.

10. Mehrotra K, Mohan C, Ranka S. Elements of Artificial Neural Networks1996;

11. Azuaje F. A computational neural approach to support the discovery of gene function and classes of cancer. IEEE Trans Biomed Eng 2001; 48:332-9.

12. Favia G, Maiorano E, Capodiferro S, Pilolli GP, Lacaita MG, Lajolo C, Giuliani M, Martinelli D, Germinario C. Oral squamous cell carcinoma: a mono-institutional epidemiological study on 462 cases highlighting differences among young and adult patients. Minerva Stomatol 2008; 57:413-21.

13. O'Brien CJ, Lauer CS, Fredricks S, Clifford AR, McNeil EB, Bagia JS, Koulmandas C. Tumor thickness influences prognosis of $\mathrm{T} 1$ and $\mathrm{T} 2$ oral cavity cancer--but what thickness? Head Neck 2003; 25:937-45.

14. Leo E, Belli F, Andreola S, Gallino G, Bonfanti G, Ferro F, Zingaro E, Sirizzotti G, Civelli E, Valvo F, Gios M, Brunelli C. Total rectal resection and complete mesorectum excision followed by coloendoanal anastomosis as the optimal treatment for low rectal cancer: the experience of the National Cancer Institute of Milano. Ann Surg Oncol 2000; 7:125-32.

15. De Stefani A, Magnano M, Bussi M, Cravero L, Lerda W, Usai A, Cavalot A, Ragona R, Gabriele P, Valente G, Cortesina G. [Identification of clinical, biological and prognostic factors in recurring squamous cell carcinoma of 
the head and neck]. Acta Otorhinolaryngol Ital 1997; 17: 219-24.

16. Bianco V, De Benedetto A, Simeoni F, Toto A, Paris E, Chiodini S, Marchei P. [Prognostic factors in operated breast carcinoma]. Minerva Med 1995; 86:17-20.

17. De Laurentiis M, Ravdin PM. A technique for using neural network analysis to perform survival analysis of censored data. Cancer Lett 1994; 77:127-38.

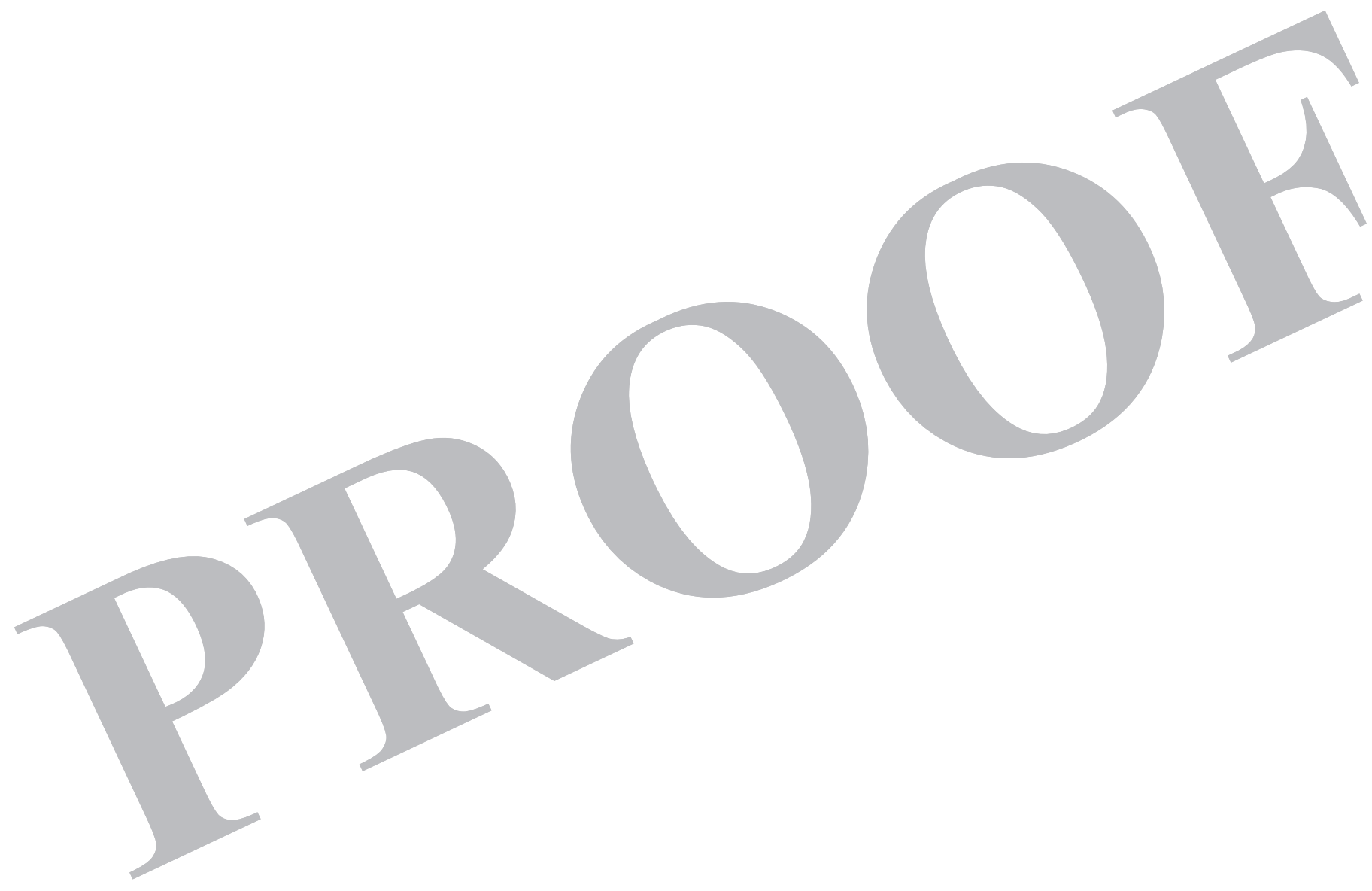

